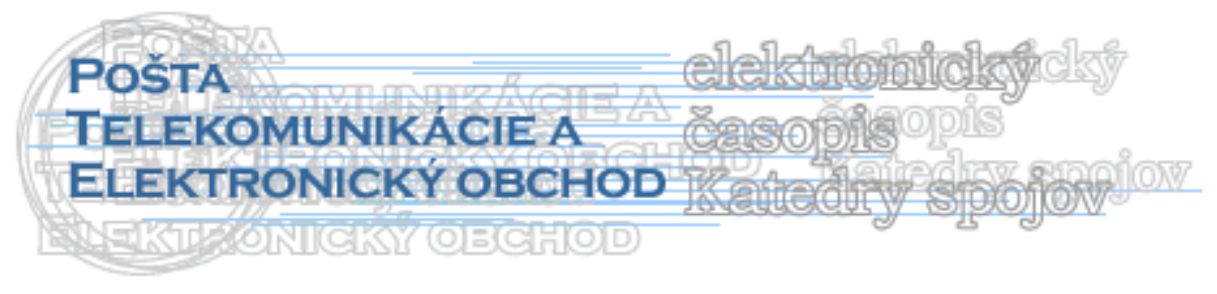

\title{
IDENTIFIKÁCIA VYBRANEJ PREPRAVNEJ JEDNOTKY V AUTOMOBILOVOM PRIEMYSLE
}

\author{
Peter Kolarovszki ${ }^{1}$ Zuzana Kolarovszká $^{2}$
}

\section{Úvod}

V súčasnej dobe je možné sledovat' nárast aplikačných možností technológií automatickej identifikácie $\mathrm{v}$ rôznych oblastiach. Jednou z nich je automobilový priemysel, ktorý má na Slovensku značné zastúpenie. Technológia RFID je prudko sa rozvíjajúca technológia, hlavne čo sa týka jej aplikačných možností. V rámci tohto článku sú popísané trendy ako aj aplikačné možnosti tejto technológie. Článok sa venuje problematike technológie RFID, jej vývojovým trendom a možnostiam aplikácie v rôznych oblastiach. Taktiež popisuje a stručne charakterizuje danú technológiu so zameraním sa na identifikáciu vybranej prepravnej jednotky - kovového skriňového kontajnera. V rámci identifikácie prepravnej jednotky boli realizované merania a výber vhodného identifikátora pre jej označovanie a identifikáciu. V záverečnej časti článku je obsiahnuté zhodnotenie vývoja trhu s RFID ako aj výsledky jednotlivých meraní.

\section{Vývoj technológie RFID a automobilového priemyslu na Slovensku}

\subsection{Vývoj technológie RFID}

Technológia rádio frekvenčnej identifikácie (RFID) nazývaná aj ako systém DSRC (Dedicated short range communication) je metóda automatickej identifikácie objektov prostredníctvom údajov uložených v RFID tagoch, ktoré sú rôzneho vyhotovenia, tvaru a vel'kostí. Údaje v tagoch slúžia na čítanie a môžu byt' editované podl'a potreby používatel'a. Čítanie a zapisovanie údajov zabezpečuje čítacie zariadenie (reader). Technológia využíva elektromagnetické pole na prenos informácií. Systém zabezpečujúci spracovanie informácií $\mathrm{z}$ tagov v dosahu čítacieho zariadenie do informačného alebo riadiaceho systému sa nazýva middleware. V praxi sa so systémom môžeme stretnút's rôznym vyhotovením.[2] Všeobecne sa systém skladá z týchto častí:

\section{RFID identifikátor (tag).}

2. Middlewar.

3. RFID čítacie zariadenia (reader).

${ }^{1}$ Ing. Peter Kolarovszki, PhD., Žilinská univerzita v Žiline, Fakulta prevádzky a ekonomiky dopravy a spojov, Katedra spojov, Univerzitná 8215/1, 01026 Žilina, Slovenská republika, tel.: +421 415133119 , fax: +421 41565 5615, e-mail: Peter.Kolarovszki@fpedas.uniza.sk

${ }^{2}$ Ing. Zuzana Kolarovszká, PhD., Žilinská univerzita v Žiline, Fakulta prevádzky a ekonomiky dopravy a spojov, Katedra spojov, Univerzitná 8215/1, 01026 Žilina, Slovenská republika, tel.: +421 415133120 , fax: +421 41565 5615, e-mail: Zuzana.Kolarovszka@fpedas.uniza.sk 
Technológia RFID napreduje rýchlym tempom, čoho výsledkom je neustály rast predaných komponentov, ako aj celková hodnota peňazí preinvestovaných $\mathrm{v}$ tejto oblasti. Neustály nárast počtu aplikácí́ technológie zvyšuje tlak na konkurenciu a núti tak čoraz viac spoločnosti nahradzovat' systémy čiarových kódov. V roku 2007 bol najväčší dopyt po RFID opät' v Č́ne a USA. Oblasti, v ktorých bola technológia využitá v značnej miere bol finančný a bezpečnostný sektor (19\%). Dôvodom bolo zavádzanie technológie pri pásovej kontrole vo viac ako 50 krajinách sveta. Priemerná cena za tag sa v roku 2008 pohybovala pri hranici 1,3 USD za kus. Viac než 2,8 miliardy USD bolo preinvestovaných v tom istom roku v Ázií, z toho 1,96 miliardy v Č́ne. V roku 2009 to bolo pokles na 5,03 miliardy USD avšak v roku 2012 nárast až na 7,67 miliardy USD. [6]

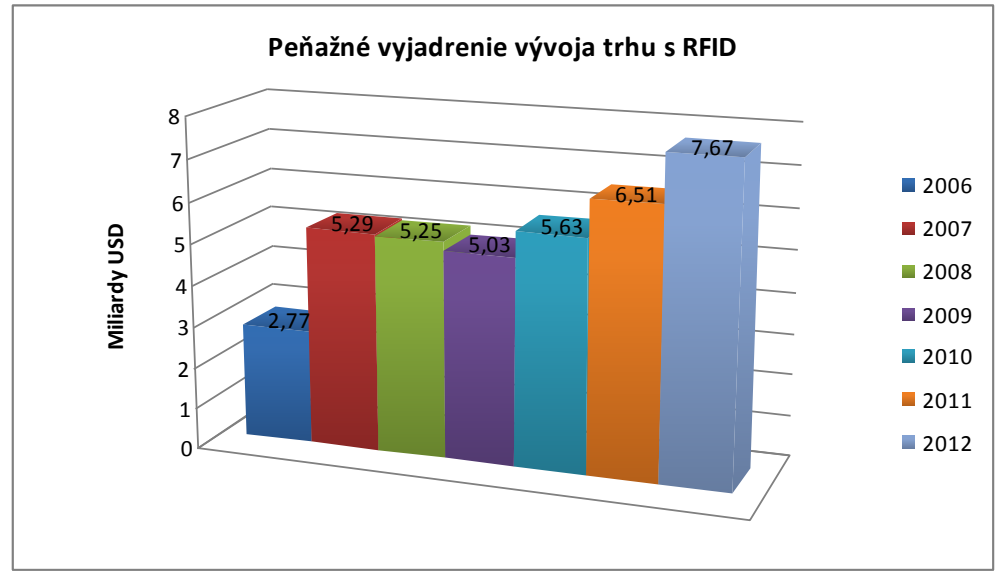

Obrázok 1. Peňažné vyjadrenie vývoja trhu s RFID (Zdroj: [6])

\subsection{Vývoj automotive na Slovensku}

Automobilový priemysel je kl’účovým priemyselným sektorom a ekonomickým pilierom viacerých krajín strednej a východnej Európy. Výrobcovia automobilov využívajú vzdelanú, produktívnu a pomerne lacnú pracovnú silu a kvalitné spojenie so západoeurópskymi trhmi ako aj výhodnú polohu pre export smerom na východ. Slovensko v súčasnosti patrí k dôležitým centrám svetového automobilového priemyslu, pričom vyrába najvyšší počet osobných automobilov na obyvatel'a na svete. Svojmu postaveniu vd'ačí najmä prítomnosti moderných závodov troch automobiliek: Volkswagen (Bratislava); PSA Peugeot Citroën (Trnava) a KIA Motors (Žilina) a globálnych dodávatel'ských podnikov. Rozvoj automobilového priemyslu na Slovensku a začlenenie sa medzi svetové automobilové centrá sa začalo v 90.-tych rokov, kedy nemecká automobilová spoločnost' Volkswagen AG spustila závod na výrobu automobilov pri Bratislave. Vstupom automobilovej spoločnosti Volkswagen na Slovensko sa začal budovat' aj dodávatel'ský ret'azec, čo pritiahlo aj d’alšie investície do krajiny. Slovensko tak nastúpilo novú cestu rozvoja priemyselnej výroby v sektoroch: automotive a strojárstvo.

Druhá významná vlna investícií do automobilového priemyslu na Slovensku bola realizovaná v rokoch 2003-2005 vd'aka príchodu d'alších dvoch automobiliek: PSA Peugeot Citroen a KIA Motors, ktoré vybudovali svoje výrobno-montážne závody pri Trnave (PSA) a Žiline (KIA). Výroba automobilov na Slovensku po nábehu výrobných liniek stúpla tak výrazne, že sa Slovensko zaradilo do prvej 20 svetových výrobcov. [8] 


\section{Prehl'ad situácie v automobilovom priemysle na Slovensku}

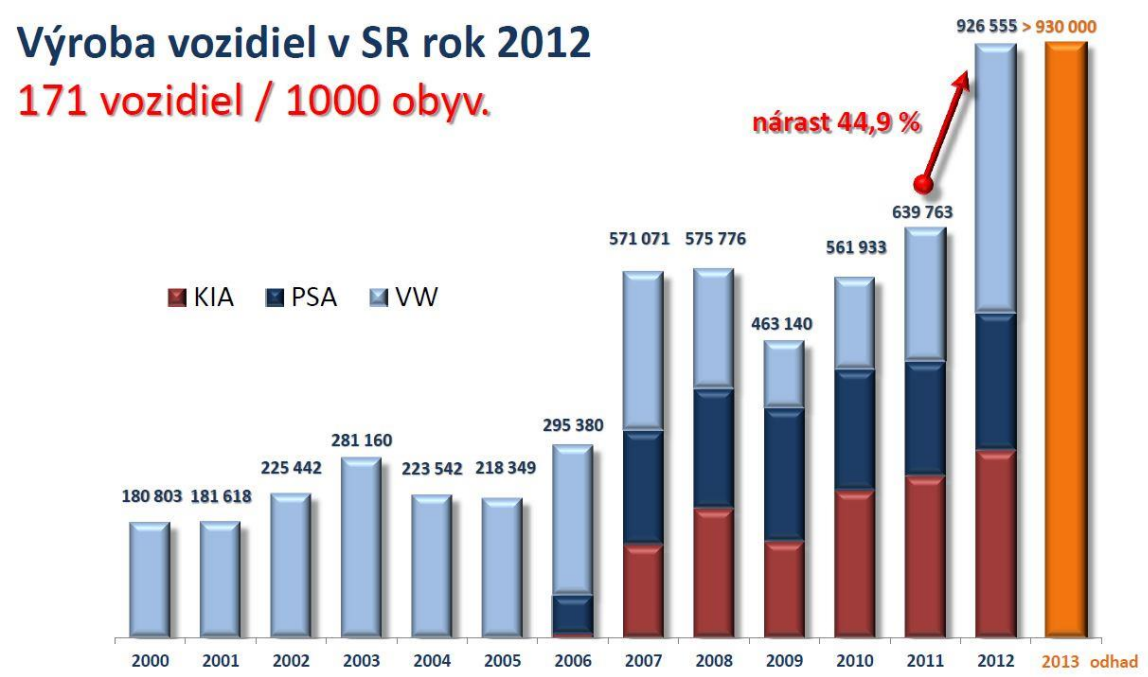

\section{$2 n$}

Obrázok 2. Situácia v automotive na SR (Zdroj: ZAP, http://www.zapsr.sk/intelligence/grafy/, citované 19.10.2013)

V roku 2011 dosiahla výroba v slovenských výrobno-montážnych automobilových závodoch 639763 osobných automobilov, čo bol vzostup oproti roku 2010 o 15\% t.j. o 83 822 automobilov viac. V roku 2012 dosiahla nárast na 926 555, čo predstavovalo nárast až o 44,9 \% oproti roku 2011. Predikciu vývoja pre rok 2013 je možné vidiet’ na obrázku 2.

\section{Identifikácia prepravnej jednotky $v$ automotive}

Ako je možné vidiet' automobilový priemysel prudko rastie a s výrobou nových automobilov rastú nároky na identifikáciu dielcov, subdodávok ako aj na vysledovatel'nost' v rámci celého logistického ret’azca. Na Slovensku je množstvo subdodávatel’ov, ktorý používajú pri preprave rôzne prepravné a manipulačné jednotky. V závislosti od štruktúry tovarov ako aj materiálu prepravných jednotiek je možné simulovat' implementáciu technológie RFID. Vyžaduje si to množstvo testov, či už čitatel'nosti RFID identifikátorov ako aj systémového prepojenia. V globálnom ponímaní je možné skonštatovat', že identifikácia prostredníctvom RFID môže byt' v rámci vnútropodnikovej logistiky subdodávatel'ského závodu alebo aj mimo podnikovej logistiky. Je možné identifikovat':

- Jednotlivé dielce.

- Prepravné jednotky (palety, prepravky, kontajnery, vozíky).

- Dokončené vozidlá.

\subsection{Konfigurácia middlewaru AMP}

Grafické rozhranie middlewaru AMP umožňuje zostavenie konfigurácie potrebnej pre prácu s RFID hardvérom. Práca v grafickom prostredí middlewaru AMP predstavuje prácu s jednotlivými elementmi, ktoré v konečnom dôsledku tvoria pravidlá a väzby pre pohyb a modifikáciu prichádzajúcich či odchádzajúcich údajov. V rámci plochy je možné vytvárat' a prepájat' jednotlivé elementy, súhrnne nazývané procesory. 


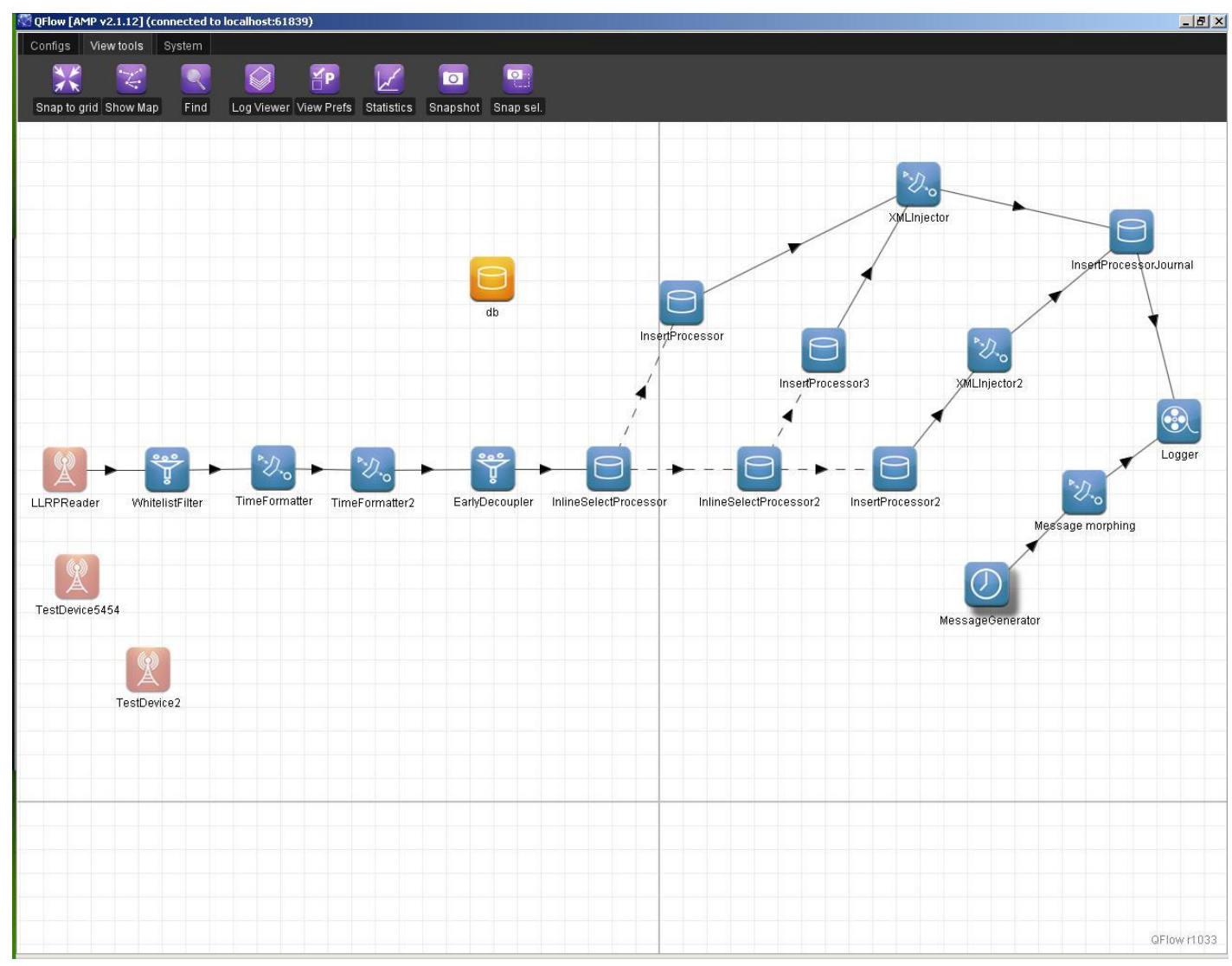

Obrázok 3. Konfigurácia Aton AMP (Zdroj: [7])

\subsection{Výber identifikátorov a popis meraní}

Merania boli uskutočnené použitím identifikátorov rôznych typov. Prvým typom použitým pri meraniach bol najbežnejšie používaný typ identifikátorov zobrazený na obrázku 4. Pri umiestnení tohto typu identifikátorov priamo na konštrukciu kontajnera dochádzalo $\mathrm{k}$ problémom pri načítavaní a to $\mathrm{z}$ dôvodu povahy materiálu použitého na výrobu konštrukcie kontajnera.

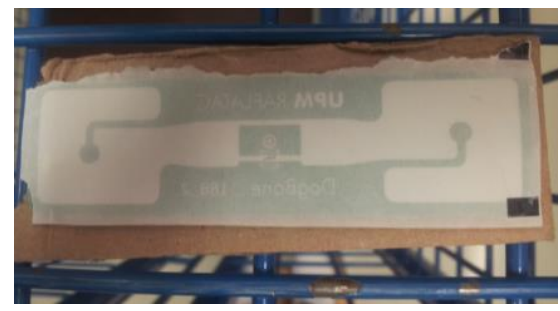

Obrázok 4. RFID identifikátor č. 11 (Zdroj: [7])

Konštrukcia kontajnera použitého počas meraní je vyrobená z ocele, teda z vodivého materiálu, ktorý pri spomínanom umiestnení daného typu identifikátorov znemožňuje ich načítanie. Čitatel'nost' tohto typu identifikátorov je možné zvýšit' použitím nevodivej podložky.

Další typ RFID identifikátorov použitých pri meraní sa vyznačuje väčšou odolnost'ou voči mechanickému poškodeniu a poveternostným vplyvom. Zaručuje to nepochybne aj plastový kryt identifikátora zobrazeného na obrázku 5. Cena tohto typu identifikátoru je však vyššia ako u prvého typu. Pri upevňovaní identifikátorov na kontajner počas merania bola použitá lepiaca páska vyhovujúca použitiu $\mathrm{v}$ laboratórnych podmienkach, pri ktorých je možné zanedbat' niektoré faktory reálneho prostredia. 


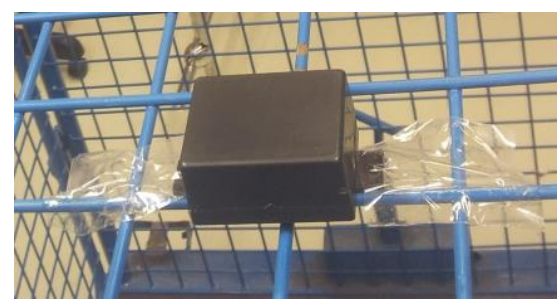

Obrázok 5. RFID identifikátor č. 22 (Zdroj: [7])

Odolnost' tretieho typu je porovnatel'ná s predchádzajúcim typom. Čip a anténa je pri tomto type vložená do gumového krytu, ktorý umožňuje dobrú manipuláciu s identifikátorom pri jeho upevňovaní. Rozdiel je však v spôsobe upevňovania tohto typu identifikátora na kontajner, čo je zobrazené na nasledujúcom obrázku.

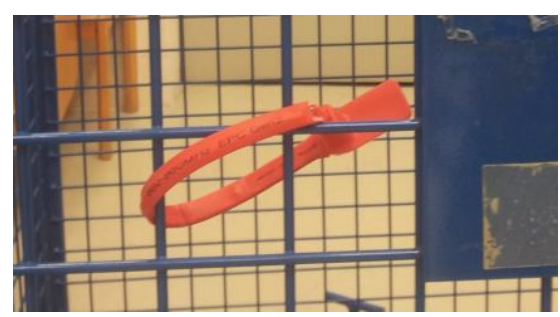

Obrázok 6. RFID identifikátor č. 31 (Zdroj: [7])

\subsubsection{Popis meraní}

Počas meraní boli použité štyri všesmerové antény napojené na čítacie zariadenie motorolla FX 7400. Jednotlivé identifikátory boli teda snímané zhora. Kontajner je vyrobený $\mathrm{z}$ väčšej časti $\mathrm{z}$ ocele, preto je potrebné vhodné umiestnenie antén čítacieho zariadenia, nakol'ko môže dochádzat' $\mathrm{k}$ tieneniu a následnému problémovému načítavaniu identifikátorov. Nemenej dôležité je tiež umiestnenie identifikátorov. Steny kontajnera sú tvorené kovovou mrežou, ktorá môže mat' za následok obmedzenie intenzity spätného signálu odrazeného od antény identifikátora.

\subsection{Výsledky meraní}

\subsubsection{Umiestnenie identifikátorov na čele kontajnera}

Jednotlivé identifikátory boli počas prvého merania umiestnené na čele kontajnera $\mathrm{V}$ usporiadaní znázornenom na nasledujúcom obrázku.

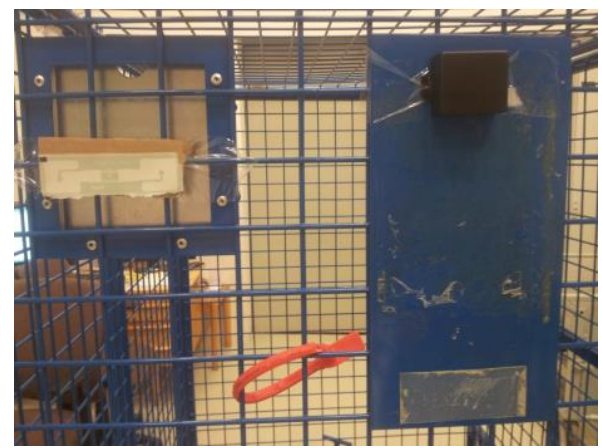

Obrázok 7. Umiestnenie RFID identifikátorov (Zdroj: [7]) 
V priebehu prvého merania boli použité štyri antény umiestnené na vrchu, tak ako počas skúšobného merania a tri RFID identifikátory troch rôznych typov. Výsledky prvého merania ukazujú vhodnost' použitia druhého a tretieho typu identifikátorov. Prehl'adné grafické zobrazenie výsledkov prvého merania je zobrazené na obrázku 8.

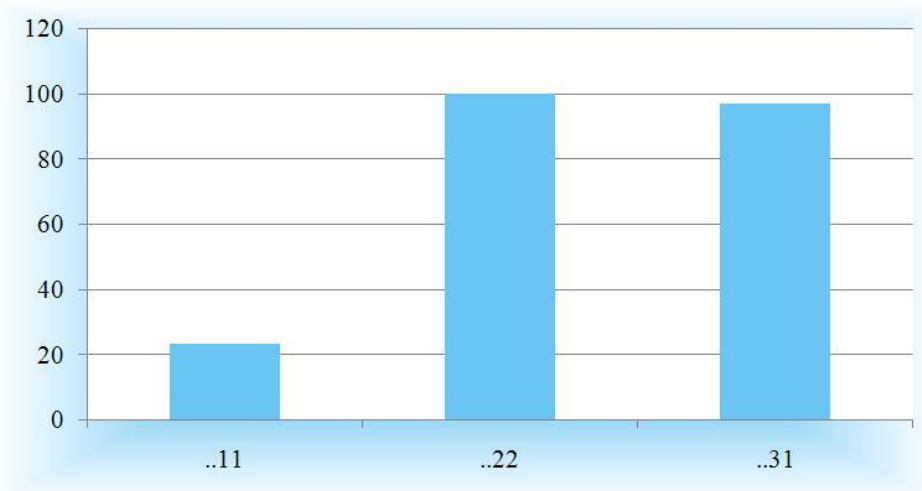

Obrázok 8. Percentuálna úspešnost’ načítavania pri prvom meraní (Zdroj: [7])

\subsubsection{Umiestnenie identifikátorov na bočnej stene kontajnera}

Druhým meraním bola zist'ovaná úspešnost' načítavania RFID identifikátorov troch zvolených typov, pričom za miesto umiestnenia identifikátorov bola pri druhom meraní zvolená bočná stena kontajnera. Priebeh druhého merania bol podobný ako v predchádzajúcom prípade, nakol'ko išlo o rovnaký pohyb kontajnera. Rozdielne umiestnenie identifikátorov malo za následok rozdielnu úspešnost' načítavania $\mathrm{v}$ prípade prvého a tretieho typu použitých identifikátorov. V prípade druhého typu sa výsledky neodlišovali od predchádzajúceho merania a znova bola dosiahnutá $100 \%$ čitatel'nost' tohto identifikátora.

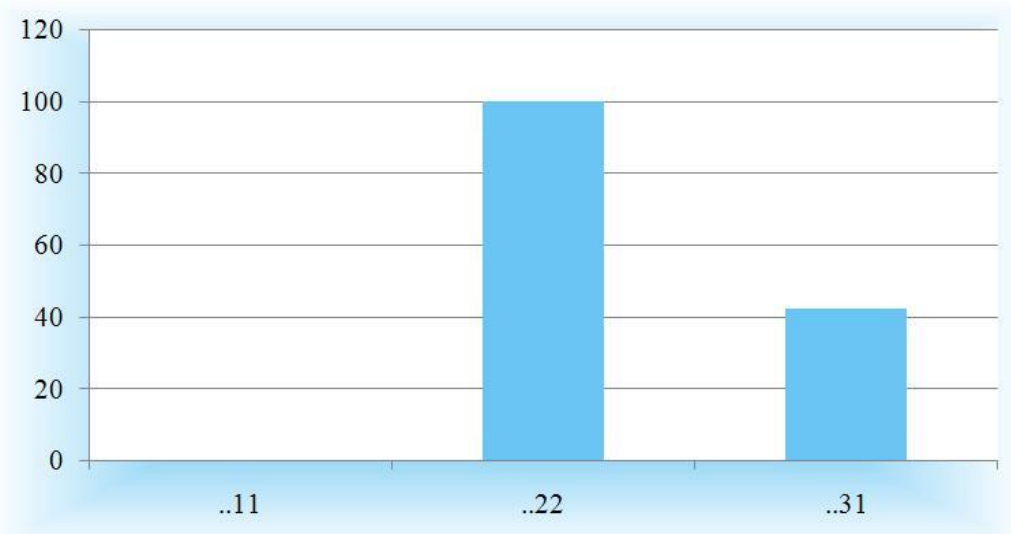

Obrázok 9. Percentuálna úspešnost’ načítavania pri druhom meraní (Zdroj: [7])

\subsubsection{Umiestnenie identifikátorov na vrchnej stene kontajnera}

Miestom umiestnenia identifikátorov u tretieho merania bola vrchná stena kontajnera. Spôsob umiestnenia identifikátorov počas tohto merania je zobrazený na nasledujúcom obrázku. 


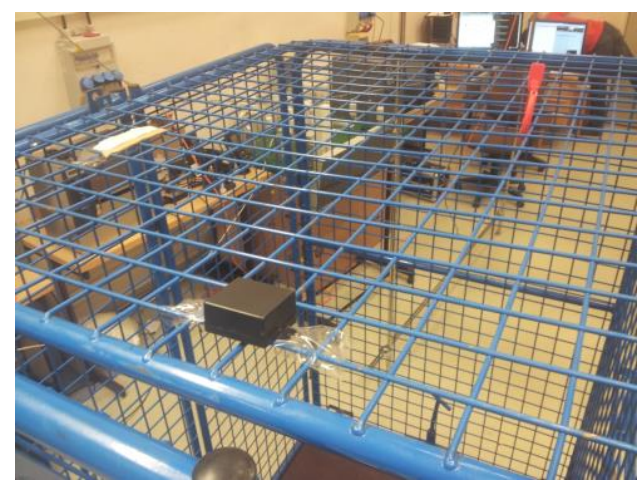

Obrázok 10. Umiestnenie RFID identifikátorov (Zdroj: [7])

Umiestnenie identifikátorov na vrchnej stene kontajnera malo za následok vysokú úspešnost' načítavania v prípade prvého, druhého aj tretieho typu použitých identifikátorov. Prvý typ identifikátorov počas tohto merania preukázal vysokú čitatel'nost'. Príčinou bola orientácia antény identifikátora voči orientácii antény čítacieho zariadenia. $\mathrm{V}$ tomto prípade išlo o vhodnú orientáciu antény identifikátora vzhl'adom na anténu čítacieho zariadenia.

Nasledujúci obrázok graficky znázorňuje percentuálnu úspešnost' načítavania jednotlivých identifikátorov.

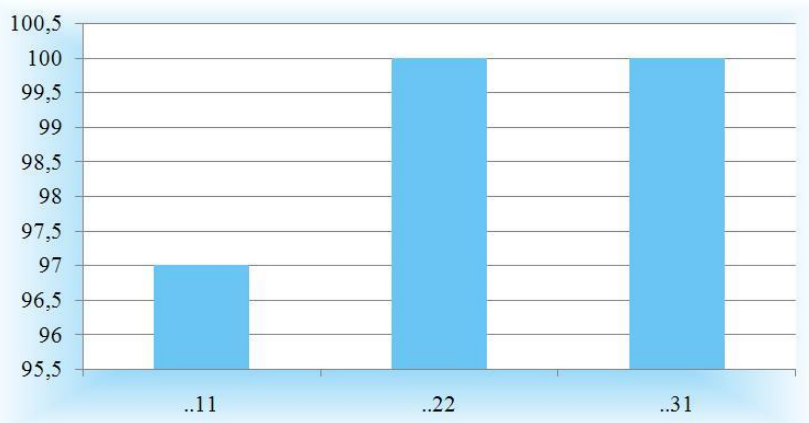

Obrázok 11. Percentuálna úspešnost’ načitavania pri tretom meraní (Zdroj: [7])

\subsubsection{Umiestnenie identifikátorov na spodnej časti kontajnera}

Identifikátory pri štvrtom meraní boli umiestnené na spodnom okraji kontajnera, ako je zobrazené na nasledujúcom obrázku.

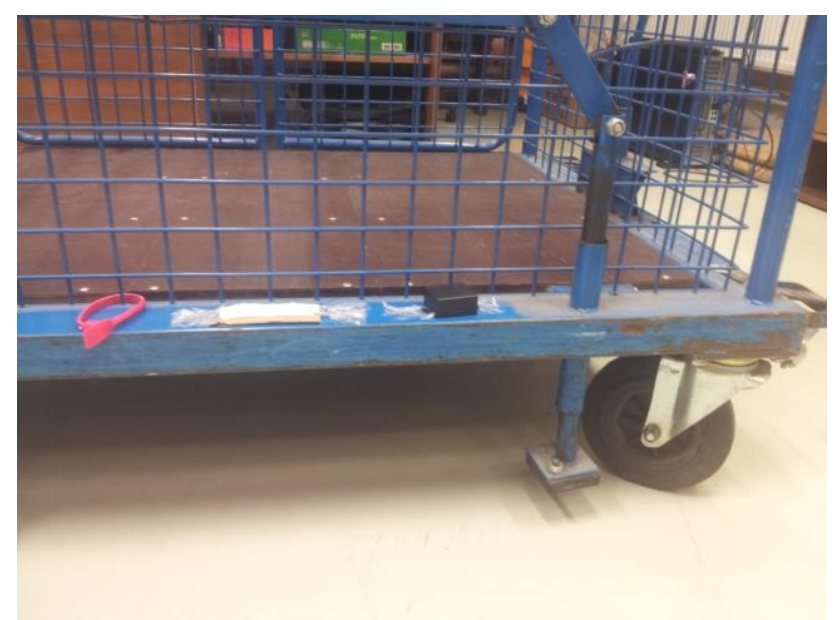

Obrázok 12. Umiestnenie RFID identifikátorov (Zdroj: [7]) 
Umiestnenie identifikátorov na spodnom okraji kontajnera malo za následok rozdielnu úspešnost' načítavania $\mathrm{v}$ prípade prvého a tretieho typu použitých identifikátorov. V prípade druhého typu sa výsledky neodlišovali od predchádzajúcich meraní, bola teda dosiahnutá $100 \%$ čitatel'nost' tohto identifikátora.

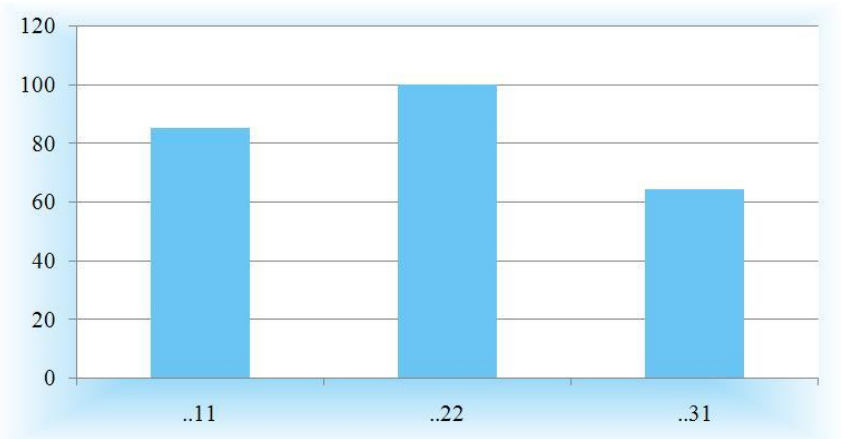

Obrázok 13. Percentuálna úspešnost’ načítavania pri štvrtom meraní (Zdroj: [7] )

\section{Záver}

Výsledky meraní ukazujú závislost' medzi orientáciou antény RFID identifikátora a orientáciou antény čítacieho zariadenia a tak isto aj v umiestnení RFID identifikátora na kovový kontajner. Druhý typ identifikátora dosiahol vo všetkých meraniach najlepšie, a to $100 \%$ výsledky, preto je na základe výsledkov spomínaných meraní najvhodnejší na identifikáciu kontajnerov v rámci dodávatel'ského ret’azca pri/počas distribúcie tovarov.

$\mathrm{Na}$ základe výsledkov meraní uskutočnených použitím dostupného technického vybavenia je druhý typ identifikátora vhodný na identifikáciu kontajnerov.

\section{Literatúra}

[1] MAŠEK, J., ČAMAJ, J., ČERNÁ L.: Possibilities of application the methods of network analysis to optimize warehouse logistics = Možnosti aplikácie metód siet'ovej analýzy pri optimalizácii skladovej logistiky, In: LOGI 2012 : 13th international scientific conference, November 22th, 2012 in Pardubice, Czech Republic : conference proceedings. - Brno: Tribun EU, 2012. - ISBN 978-80-263-0336-7. - S. 257-263.

[2] TENGLER, J., VACULÍK, J.: Notifikace doručení poštovních zásilek prostřednictvím mobilního telefonu $=$ Notification of delivery postal mail trough mobile phone / In: POSTPOINT 2013 [elektronický zdroj] : „Delivering innovation and training in postal technology and services" : [10.] medzinárodná konferencia zástupcov poštových správ a univerzít : Rajecké Teplice, Slovakia, 19.-20. september 2013 : zborník príspevkov. Žilina: Žilinská univerzita, 2013. - ISBN 978-80-554-0747-0. s. 189-196.

[3] MICHÁLEK, I., VACULÍK, J.: RFID planning levels for postal and courier services. In: Future Role of Postal Services in the Face of New Market Conditions and Communication Technologies, Pardubice, Czech republic, December, 2008 (pp. 144151). Pardubice: University of Pardubice.

[4] FINKENZELLER, K.: RFID Handbook: Fundamentals and Applications in Contactless Smart Cards, Radio Frequency Identification and Near-Field Communication. UK: John Wiley \& Sons, Ltd.., 2010. 40 s. ISBN 978- 0470695067

[5] KOLAROVSZKI, P. Day of new Technologies: Vývoj technológie RFID a jej komponentov v nasledujúcom období. [CD-ROM] Žilina: EDIS, 2010. 105 s. ISBN 978-80-554-0279-6. 
[6] JURKO, P.: Vývojové trendy technológie RFID a možnosti jej aplikácie [Bakalárska práca]. Žilinská univerzita v Žiline. Fakulta prevádzky a ekonomiky dopravy a spojov; Katedra spojov, 2013.

[7] PALUV, P.: Identifikácia poštových kontajnerov prostredníctvom technológie RFID Diplomová práca. Žilinská univerzita v Žiline. Fakulta prevádzky a ekonomiky dopravy a spojov; Katedra spojov, 2013.

[8] SARIO - Slovenská agentúra pre rozvoj investícií a obchodu, 2012, interný materiál

\section{Grantová podpora}

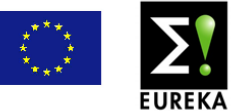

E!7592 AUTOEPCIS - RFID Technology in Logistic Networks of Automotive Industry (RFID technológie v logistických siet'ach automobilového priemyslu) Za podpory Ministerstva školstva, vedy, výskumu a športu.

- IV 2/KS/2013 Výskum uplatnenia AIDC technológií v poštových a logistických procesoch a ich overenie $v$ laboratórnych podmienkach 